\title{
Kişilik Özelliklerinin Psikolojik Dayanıklılık Üzerindeki Etkisi
}

\author{
DOI: $10.26466 /$ opus. 827411
}

*

\author{
Sema Polatc1* - Zeynep Dilara Tinaz ** \\ * Doç. Dr., Tokat Gaziosmanpaşa Üniversitesi, İktisadi İdari Bilimler Fakültesi, Tokat/Türkiye \\ E-Posta: sema.polatc1@gop.edu.tr \\ ORCID: $\underline{0000-0002-4671-1356}$ \\ ** Öğr. Gör., Tokat Gaziosmanpaşa Üniversitesi, Meslek Yüksekokulu, Tokat/Türkiye \\ E-Posta: zeynepdilara.tinaz@gop.edu.tr \\ ORCID: 0000-0002-8063-9749
}

\begin{abstract}
Öz
Bu çalışmanın amacı kişilik özelliklerinin psikolojik dayanıklılık üzerindeki etkisini ortaya çıkarmaktır. Araştırmanın örneklemini 423 meslek yüksekokulu öğrencisi oluşturmaktadır. Araştırma verileri Beş Faktör Kişilik Envanteri ve Yetişkinler İçin Psikolojik Dayanıklılık Ölçeği kullanılarak elde edilmiştir. Elde edilen verilere fark, korelasyon ve regresyon analizleri yapılmıştır. Analiz sonucunda kişilik özelliklerinden uyumluluk ve duygusal dengenin cinsiyet değişkenine göre farklllık gösterdiği tespit edilmiştir. Buna göre kadınlar uyumluluk özelliği açısından, erkekler ise duygusal denge özelliği açısından karşı cinsten yüksek ortalamaya sahiptirler. Araştırma sonuçları doğup büyüdü̈̆̈̈ yer ile eğitim aldığ yer aynı olan katılımcıların öz disiplin ortalamasının doğup büyüdü̈̆̈̈ yer ile eğitim aldığı yer ayn olmayan katılımcıların öz disiplin ortalamasından yüksek olduğunu da ortaya koymaktadır. Yine bulgulara göre psikolojik dayanıklılık da cinsiyete göre farklılık göstermektedir. Kadınların erkeklere görece daha yüksek psikolojik dayanıklılık ortalamalarına sahip olduğu ortaya koyulmuştur. Araştırma sonuçları öğrencilerin kişilik özelliklerinden gelişime açıklı, öz disiplin, dışa dönüklük ve uyumluluğun psikolojik dayanıklılıkların pozitif yönde etkilediğini göstermiştir. Ayrıca kişilik özelliklerinin dayanıklılı$\breve{g}$ ın alt boyutların etkilediği de elde edilen sonuçlar arasındadır. Kişilik özelliklerinden öz disiplinin dayanıklılğıı tüm boyutlarını, duygusal dengenin ise sadece kendilik algısı boyutunu etkilediği tespit edilmiştir.
\end{abstract}

Anahtar Kelimeler: Kişilik Özellikleri, Psikolojik Dayanıkllık, Üniversite Öğrencileri 
ISSN: 2528-9527

E-ISSN : 2528-9535

YIl Year: 11

Cilt Volume: 17

Sayı Issue:36

\title{
The Effect Of Personality Traits On Psychological Resilience Abstract
}

\begin{abstract}
The aim of this study is to reveal the effect of personality traits on psychological resilience. The sample of the research consist of 423 vocational school students. The research data were obtained by Five Factor Personality Inventory and the Adult Psychological Resilience Scale. Difference, correlation and regression analyses were performed. As a result of the analysis, it was determined that agreeableness and emotional stability differ according to the gender variable. According to this, females have a higher average in terms of agreeableness and males in terms of emotional stability feature compared to the opposite sex. It is also among the results that conscientiousness, which is one of the personality traits, differs in terms of the place of residence. The results of the research also reveal that the conscientiousness average of the participants whose place of birth and education is the same as the place is higher than the conscientiousness average of the participants whose place of birth and education is not the same. Again, according to the findings, psychological resilience also varies according to gender. It has been shown that women have higher averages of psychological resilience than men. The results of the research showed that openness to experience, conscientiousness, extraversion and agreeableness from personality traits of students positively affect their psychological resilience. It is also among the results that personality traits affect the sub-dimensions of resilience. It is determined that conscientiousness, which is one of the personality traits, affects all dimensions of resilience and emotional stability affects only perception of self.
\end{abstract}

Keywords: Personality Traits, Psychological Resilience, University Student 


\section{Giriş}

Bir çalışan işyerinde görevini yerine getirirken neredeyse her gün pek çok zorlukla karşı karşıya gelmektedir. Psikolojik açıdan dayanıklı olmak, bireyin işi dâhil yaşamının her alanında karşılaştığı bu zorlukları aşması için imkân sağlayan olumlu bir özelliktir. İş yaşamında karşılaşılan zorlukların üstesinden gelmenin hem çalışan hem de örgüt için birçok olumlu sonuca yol açtı̆̆1 deneysel olarak da ortaya konulmuştur (Erkutlu, 2012; Chitra ve Karunanidhi, 2013; García-Izquierdo, Meseguer de Pedro, Ríos-Risquez, ve Sánchez, 2018; Kaba ve Keklik, 2016; Karacabey ve Bozkuş, 2019; Kashyap, Kumar, ve Krishna, 2014; Li, Cao, Cao, ve Liu, 2015; Yang, Tang, ve Zhou, 2017). Bu sebeple çalışanların psikolojik dayanıklılığını etkileyen faktörlerin ortaya çıkarılması örgütsel davranış disiplini açısından önem arz eden konulardan birisidir.

Dayanıklılığın geleneksel risk ve korunma kavramlarından farklılık gösterdiği ve odak noktasında kişisel farklılıklar olduğu ifade edilmektedir (Rutter, 2006, s.1). Her insanın fiziksel, biyolojik ve ruhsal yapısı birbirinden farklıdır. Hatta fiziksel özellikleri açısından benzeyen iki insan bile birbirinden olağanüstü derecede farklllık gösterebilmektedir. Herhalde evrende birbirine bu kadar benzeyip de aynı zamanda bu kadar farklı olan çok az şey vardır. Bireyin farklılığının en önemli sebebi onu diğerlerinden ayıran, milyarlarca insan içinde sadece ona özel olan kişiliğidir. Kişiliğin birçok örgütsel sonuç üzerinde etkili olduğu bilinmektedir (Acaray ve Günsel, 2017; Ahmad, Jasimuddin, ve Kee, 2018; Erkuş, 2011; Huang, Ryan, Zabel, ve Palmer, 2014; Neal, Yeo, Koy, ve Xiao, 2012; Ötken ve Cenkci, 2013; Şimşek ve Aktaş, 2015; Ulu, Özdevecioğlu, ve Ardıç, 2016; Tatar vd., 2019). Bu bilgilerden hareketle bu çalışmanın amacı, kişiliğin psikolojik dayanıklılık üzerindeki etkisini ortaya çıkarmak, hangi kişilik özelliklerine sahip bireylerin psikolojik açıdan daha dayanıklı olduğunu tespit edebilmektir. Bu çalışmada ayrıca kişilik özelliklerinin psikolojik dayanıklılığın alt boyutları üzerindeki etkisi de araştırılmıştır.

Kişilik üzerinde önemli çalışmaları bulunan W. Allport "iki insan arasındaki fark, iki hayvan arasındaki farktan çok daha karmaşıktır" demektedir (Yurtsever, 2009, s. 21). Kişilik insanları birbirinden, hatta diğer canlılardan ayıran özelliklerden biridir. Farklı kişilikteki bireyler aynı durum ve olaylara 
farklı karşılık verebilirler. Yönetim psikolojisi de belirli amaçları etkin ve verimli bir şekilde gerçekleştirmek için bu bireysel farklılıklardan nasıl yararlanılacağını araştırmaktadır (Erol, 2010, s. 98). İnsanı benzersiz kılan, kişilik olgusunun temelini oluşturan bu farklllıkları işlevsel hale getirmek örgütler açısından önem arz etmektedir. Bu farklılıkları örgütler açısından kazanca dönüştürmek, örgüte ve ona verilecek göreve uygun kişilikteki bireyleri örgüte kazandırmakla mümkün olabilmektedir (Polatçı, Sobacı, ve Kaban, 2019, s. 13).

Kişiliğin tanımı konusunda fikir birliğine varılamamıştır. Ancak alan yazın incelendiğinde kişilik tanımlarının büyük ölçüde bireysel farklılıkları vurguladığı görülmektedir (Yazgan İnanç ve Yerlikaya, 2011, s. 3). Kişiliği “bir insanı başkalarından ayıran duyuş, düşünüş ve davranış tarzlarını etkileyen faktörlerin kendine özgü örüntüsü" (Baymur, 2017, s. 275) olarak tanımlamak mümkündür. Kişiliğin pek çok olgu üzerinde etkili olduğu düşünüldüğünden değerlendirilmesi de her zaman önem arz eden bir konu olmuştur. Endüstri/örgüt psikologları bir mesleğe uygun en iyi adayı seçmek, danışman psikologlar/psikolojik danışmanlar bir adaya uygun en iyi işi bulmak, bir pozisyonun gereklilikleri ile bir kişinin ilgi ve ihtiyaçlarını eşleştirmek için kişiliği ölçmek istemektedirler (Schultz ve Schultz, 2013, s. 11).

İnsanın kendisini tanımlamaya yönelik çabalarının kendi tarihi kadar eski olduğunu söylemek mümkündür. Kişiliği anlamak üzere birçok farklı kuram ve yaklaşım geliştirilmiştir. Bu durum kişiliği ölçmek için farklı ölçüm yöntemlerinin kullanılmasına da imkân sağlamaktadır. Bu kuramlardan araştırma odaklı ayırıcı özellik yaklaşımı kişilik psikolojisinde kabul gören bir yaklaşımdır (Yazgan İnanç ve Yerlikaya, 2011, s. 241). Kişiliği faktörlere dayalı olarak açıklayan ve yürütülen çalışmalarda birçok defa boyutları doğrulandığı için "beş faktör" olarak adlandırılan model ayırıcı özellikler yaklaşımı içinde yer almaktadır (Burger, 2006, s. 251). 1980'den sonra birçok araştırmada kullanılan bu model üzerinde gittikçe artan bir fikir birliği olduğu söylenebilir (Goldberg, 1995). Bu modele dayalı olarak geliştirilen beş faktör kişilik envanteri kişinin kendi kendini değerlendirdiği bir ölçektir (Gençtanırım Kurt ve Çetinkaya Yıldız, 2017, s. 25) ve boyutları şu şekilde sıralanmaktadır (McCrae ve Costa, 2003, s. 2): gelişime açıklık, öz disiplin, dişa dönüklük, uyumluluk ve duygusal denge. 
Gelişime açıklık (openness to experience) meraklı, bağımsız, yaratıcı, geniş hayal gücü, değişikliği sevme, geleneksel olmama; öz disiplin/sorumluluk (conscientiousness) yeterli, düzenli, titiz, ihtiyatlı, başarı çabası; dışa dönüklük (extraversion) hareketli, enerjik, baskın, sosyal, etkileyici ve pozitif duygulara sahip olma; uyumluluk/yumuşak başlılık (agreeableness) nazik, saygıll, açık kalpli, merhametli olma; duygusal denge (tersi-neuroticism) hüzünlü, gergin, tedirgin, huzursuz, sabırsız olmama gibi sıfatlarla tanımlanmaktadır (Costa, McCrae, ve Dye, 1991; Barric ve Mount, 1991; BenetMartínez ve John, 1998; Somer, Korkmaz, ve Tatar, 2002).

Olumsuz şartlar karşısında kimi bireyler direnç gösterip daha başarılı olurken, kimi bireyler ise pes edip kolayca vazgeçebilmektedir. Diğerlerine oranla olumsuz koşullara daha fazla direnç gösteren bireylerin daha dayanıklı olduğu söylenebilmektedir. Psikolojik dayanıklılık yıkıcı bir olaya maruz kalan yetişkinlerin nispeten istikrarlı bir psikolojik ve fiziksel işlevsellik seviyesini koruyabilmesi anlamına gelmektedir (Bonanno, 2004, s. 102). Bireylerin göstermiş oldukları farklı dayanıklılık seviyeleri alan yazında iki farklı bakış açısı tarafından açıklanmıştır. İlk bakış açısı psikolojik dayanıkl1lığa sahip olan bireylerin kişilik özelliklerine, ikincisi ise dayanıklılık sürecinin nasıl geliştiğine odaklanmaktadır (Çetin, Yeloğlu, ve Basım, 2015, s. 82). Bu çalışmada ilk bakış açısı referans alınarak kişilik özelliklerinin psikolojik dayanıklılık üzerindeki etkisi araştırılmıştır.

Araştırmacılar tarafından dayanıklılığı etkileyen birçok faktör olduğu ifade edilmekle birlikte, bu faktörler kişisel (olumlu mizaç, dil ve öğrenme hünerleri, öz sayg1...); ailesel (ailenin samimiyeti, teşviki, yardımı...) ve sosyal (destekleyici akranlar, olumlu öğretmen etkisi, cezalandırıcı olmayan çevre...) olmak üzere üç grupta sınıflandırılmaktadır (Olsson, Bond, Burns, Vella-Brodrick, ve Sawyer, 2003, s. 11). Alan yazında psikolojik dayanıklılığ1 ölçmek için farklı ölçekler geliştirildiği görülmektedir. Bu ölçeklerden yetişkinler için psikolojik dayanıklılık ölçeği yetişkinlerin direncini artıran koruyucu faktörlere odaklanmakta olup boyutları şu şekilde sıralanmaktadır (Friborg, Hjemdal, Rosenvinge, ve Martinussen, 2003, s. 65): kendilik algis1, gelecek algısı, sosyal yeterlilik, aile uyumu, sosyal kaynaklar ve yapısal stil.

Kendilik algısı (perception of self) kişinin kendinin farkında olmasını; gelecek algısı (perception of future) kişinin geleceğe yönelik bakış açısını; sosyal yeterlilik (social competence) kişinin sosyal açıdan destek görüp görmedi- 
ğini; aile uyumu (family cohesion) kişinin en yakınlarıyla olan uyumunu; sosyal kaynaklar (social resources) kişinin sahip olduğu sosyal ilişkileri; yapısal stil (structured style) de kişinin kendine güvenini, öz disiplinini tanımlamaktadır (Çetin ve Basım, 2011, s. 83; Friborg v.d., 2005, s.34 )

Boyutlu yapısı birçok defa doğrulanan beş faktör kişilik modeli kullanılarak yapılan çalışmalarda kişiliğin, iş performansı (Barric ve Mount, 1991; Dalton ve Wilson, 2000; Ono, Sachau, Deal, Englert, ve Taylor, 2011); lider-izleyici etkileşimi (Erkuş, 2011); iş rolü performansı (Neal vd., 2012); öznel iyi oluş (Doğan, 2013; Zhai, Willis, O'Shea, Zhai, ve Yang, 2013); çatısma çözme yaklaşımları (Basım, Çetin, ve Tabak, 2009; Yıldızoğlu ve Burgaz, 2014; Erkuş ve Tabak, 2009; Tozkoparan, 2013; Tekin, Turan, Özmen, Turhan, ve Kökçü, 2012); iş değerleri (Merdan, 2013); iş tatmini (Kardaş, 2018; Turhan, 2019; Bayat, 2019; Zhai vd., 2013; McCann, 2018); özyeterlik (Bahar ve Kağan, 2018); izlenim yönetimi (Tabak, Basım, Tatar, ve Çetin, 2010); akademik güdülenme (Bitlisli, Dinç, Çetinceli, ve Kaygısız, 2013); tükenmişlik (Dinç, Bitlisli, Çetinceli, ve Aydın, 2013; Armon, Shirom, ve Melamed, 2012; Santos, Mustafa, ve Chern, 2016; Bakker, Van Der Zee, Lewig, ve Dollard, 2006); örgütsel bağlllık (Sood ve Puri, 2016); örgütsel muhalefet (Ötken ve Cenkci, 2013); girişimcilik (Antoncic, Bratkovic Kregar, Singh, ve Denoble, 2015); grup uyumu (Joardar ve Matthews, 2010) gibi değişkenlerle ilişkisi ortaya koyulmuştur. Kişilik özelliklerinin meslek gruplarına göre farklılık gösterdiği de (Somer, 2001) deneysel olarak kanitlanmıştır.

Öte yandan kişilik özellikleri ile psikolojik dayanıklılık arasındaki ilişki ve etkileşimi ortaya koyan çalışmalar mevcuttur (Davey, Eaker, ve Walters, 2003; Fayombo, 2010; Liu, Wang, ve Li, 2012; Farradinna, Nila Fadhlia, ve Azmansyah, 2019). Furnham ve arkadaşları (1997) kişilik özelliklerinin başarma güdüsü, önsezi, dayanıklılık gibi faktörler üzerinde etkili olduğunu tespit etmişlerdir. Riolli ve arkadaşları (2002) dayanıklılığın, yüksek dışa dönüklük, gelişime açılık ve öz disiplin; düşük duygusal dengesizlik ile ilişkili olduğunu ortaya koymuştur. Campbell-Sills ve arkadaşları (2006) dayanıklı̆̆ın öz disiplin ve dışadönüklüğü pozitif, duygusal dengesizliği ise negatif yönde etkilediğini açığa çıkarmışlardır. Çetin ve arkadaşları (2015) yaptıkları araştırmada dişadönüklük, öz disiplin, gelişime açılık ve uyumluluk seviyesi yüksek nevrotiklik seviyesi düşük bireylerin daha dayanıklı olduğunu ortaya koymuşlardır. Polatcı ve arkadaşları (2017) dayanıklılık ile duygusal denge- 
sizlik arasında negatif, diğer tüm kişilik boyutları ile pozitif yönlü bir etkileşim olduğunu ortaya koymuştur. Alan yazındaki bu bilgiler ışığında araştırmanın ilk hipotezi şu şekilde tasarlanmıştır:

- $H_{1}$ : Kişilik özellikleri psikolojik dayanıklılığı etkilemektedir.

Alan yazında kişilik özelliklerinin psikolojik dayanıklılı̆̆ın alt boyutları ile olan ilişkisini inceleyen çalışmalar da mevcuttur. Friborg ve arkadaşları (2005) yapmış oldukları çalışmada bütün dayanıklılık boyutlarının kişilik özellikleri ile ilişkili olduğunu tespit etmişlerdir. Çavuşoğlu ve Yalçın (2018) ise kişilik özelliklerinin dayanıklılığın alt boyutlarını etkilediğini tespit etmiştir. Bahsi geçen bu bilgiler ışığında dayanıklılığın alt boyutlarını etkilemede hangi kişilik özelliklerinin ön plana çıktığını tespit edebilmek için araştırmanın ikinci hipotezi aşağıdaki gibi tasarlanmıştır:

- H2: Kişilik özellikleri psikolojik dayanıklhı̆̆ın alt boyutlarnn etkilemektedir.

\section{Yöntem}

\section{Ana Kütle ve Örneklem}

Araştırmanın ana kütlesini Tokat ilinde öğrenim gören meslek yüksekokulu öğrencileri oluşturmaktadır. Araştırma verileri 2020 yılı öncesi toplanmıştır. Tokat Gaziosmanpaşa Üniversitesi'nin resmi internet sitesinden alınan verilere göre meslek yüksekokullarında 4.666 kız, 7.922 erkek olmak üzere toplam 12.588 öğrenci eğitim görmektedir. Örneklemin belirlenmesinde "Farklı Evrenler İçin Kabul Edilebilir Asgari Örneklem Büyüklükleri” (Gürbüz ve Şahin, 2016, s. 132) tablosundan yararlanılmıştır. Buna göre \%95 güven aralığında, ana kütle 12.588 iken örneklemin 375 olması yeterlidir.

Örnekleme tekniği olarak olasılığa dayalı olmayan örnekleme yöntemlerinden biri olan kolayda örnekleme tekniği kullanılmıştır. Cevaplandırılacak anket sayısı, bazı anketlerin eksiklikler sebebiyle değerlendirme dışı bırakılma ihtimaline karşı, en az 500 olarak belirlenmiştir. Dağıtılan anketlerden 441 tanesi katılımclar tarafından cevaplandırılmıştır. Bunların 18 tanesi demografik değişkenlerin boş bırakılması veya ifadelerin çoğunun cevaplanmaması gibi sebeplerle değerlendirme dışı bırakılmıştır. Sonuç olarak, 423 anket araştırma için değerlendirmeye alınmıştır.

Araştırma örneklemini oluşturan katılımcıların \%74,5' i kız, \%25,3'ü erkek, \%27'si 18-19 yaşında, \%42,8' i 20-21 yaşında, \%15,4'ü 22 ve üzeri yaştadır. Yaş 
ortalaması 20,8'dir. Katılımcıların \%43,5'i Çocuk Gelişimi, \%12,1'i Büro Yönetimi, \%8,5'i Bankacılık ve Sigortacılık, \%7,6'sı Bilgisayar Programcllı̆ $\% 5,6$ 'sı Maliye, \%4,7'si muhasebe, $\% 4,3$ 'ü işletme yönetimi programında eğitim görmektedir. Bu öğrencilerin $\% 42,8$ 'i birinci sınıf, \%54,4'ü ikinci sınıf, $\% 6$ 'sı uzatma öğrencisidir. Yine bu öğrencilerin \%64,8' inin alttan dersi bulunmakta, \%33,1'inin ise bulunmamaktadır. Alttan dersi olanların \%22,5'inin 1, $\% 16,5^{\prime}$ inin 2, \%23,6'sının 3 ve daha fazla alttan dersi vardır.

Katılımciların \%34,8'i ailesiyle birlikte, \%30'u öğrenci evinde, $\% 34,3$ 'ü yurtta kalmakta, \%75,4'ünün ikameti Tokat ilinde, \%19,1'inin Tokat dışında bir ilde bulunmaktadır. Katılımcların \%49,9'u 0-499 TL, \%27,7'si 500-999 TL, \%3,5'i 1.000-5.000 TL arasında gelirleri olduğunu ifade etmektedirler. Gelir ortalaması yaklaşık 450 TL'dir.

\section{Veri Toplama Araçlar}

Araştırmada kişilik özelliklerini ve psikolojik dayanıklılığı belirleyebilmek için Kişilik Özellikleri Ölçeği ve Psikolojik Dayanıklılık Ölçeği kullanılmıştır. Ölçekler 5'li likert tipinde hazırlanmıştır. Bu bölümde katılımcılardan verilen ifadelere katılma düzeylerini belirtmeleri istenmiştir. Buna göre bir katılımcı ilgili ifadeye katılma düzeyini "kesinlikle katılmıyorum:1", "katılmıyorum:2", "ne kat1lıyorum ne katılmıyorum:3", "katılıyorum:4", "kesinlikle katılıyorum:5" şeklinde ifade etmiştir. Ölçeklere ilişkin daha detaylı bilgiler aşağıda verilmiştir.

Kişilik Özellikleri Ölçeği: Kişilik özelliklerini ölçmek için Benet-Martinez ve John (1998) tarafından geliştirilen 44 ifadeden oluşan, “Beş Faktör Kişilik Envanteri" kullanılmıştır. Ölçek "gelişime açılık”, “öz disiplin”, “dışa dönüklük", "uyumluluk" ve "duygusal denge" olmak üzere beş boyuttan oluşmaktadır. Ölçeğin güvenirliliği için hesaplanan Cronbach's alpha değeri 0,82'tir. Alt boyutların güvenirliliği ise 0,53 ile 0,71 arasında değişmektedir. Güvenirlilik için hesaplanan Cronbach's alfa değeri inceleme türü araştırmalarda 0,50'e kadar makul kabul edilebilmektedir (Altunışık, Coşkun, Bayraktaroğlu, ve Yıldırım, 2004, s. 115)

Psikolojik Dayanıklılık Ölçeği: Psikolojik dayanıklılığı ölçmek üzere ise Fribog ve arkadaşları (2005) tarafından geliştirilen, 33 ifadeden oluşan "Yetişkinler İçin Psikolojik Dayanıklılık Ölçeği” kullanılmıştır. Ölçeğin Türkçe'ye 
uyarlaması Basım ve Çetin (2011) tarafından yapılmıştır. Ölçek “kendilik algisı", "gelecek algisı", "sosyal yeterlilik", "aile uyumu" "sosyal kaynaklar" ve "yapısal stil" olmak üzere altı boyuttan oluşmaktadır. Ölçeğin yapısal stil boyutunda yer alan "Yeni bir işe/projeye başladığımda planlama yapmam, derhal işe başlarım." ifadesi güvenirliği düşürdüğü için ölçekten çlkarılmış, analize dâhil edilmemiştir. Ölçeğin güvenirlilik için hesaplanan Cronbach's alfa değeri $0,88^{\prime}$ dir. Alt boyutların güvenirliliği ise 0,51 ile 0,69 arasında değişmektedir.

\section{Bulgular}

Araştırma verilerinin değerlendirilebilmesi için SPSS programından faydalanılmışır. Katılımcıların demografik özelliklerine ilişkin tanımlayıcı analizler yapabilmek için frekans gibi temel istatistikler hesaplanmıştır. Gruplar arası farklılıkları tespit edebilmek için "bağımsız iki grup arası T-testi", "tek yönlü varyans analizi (one-way ANOVA)" ve post hoc testlerinden "Scheffe" testi uygulanmıştır. Kişilik özellikleri ile psikolojik dayanıklılık arasındaki ilişki ve etkileşimi ölçmek amacıyla da korelasyon ve regresyon katsayıları hesaplanmıştır. Değişkenlere ilişkin korelasyon katsayıları Tablo 1'de verilmiştir.

Tablo 1. Değişkenler Arasındaki Korelasyon Katsayısı

\begin{tabular}{llllllllllll}
\hline Değişkenler & 1 & 2 & 3 & 4 & 5 & 6 & 7 & 8 & 9 & 10 & 11 \\
\hline 1.Gelişime açıllık & & & & & & & & & & & \\
2.Öz disiplin &, $447^{* *}$ & & & & & & & & & \\
3.Dışa dönüklük &, $484^{* *}$ &, $250^{* *}$ & & & & & & & & \\
4.Uyumluluk &, $534^{* *}$ &, $602^{* *}$ &, $293^{* *}$ & & & & & & & & \\
5.Duygusal denge &, 088 &, 094 &, $194^{* *}$ &, $135^{* *}$ & & & & & & & \\
6.Kendilik algis1 &, $495^{* *}$ &, $497^{* *}$ &, $716^{* *}$ &, 461 &, $227^{* *}$ & & & & & & \\
7.Gelecek algisı &, $406^{* *}$ &, $477^{* *}$ &, $358^{* *}$ &, $411^{* *}$ &, $160^{* *}$ &, $392^{* *}$ & & & & & \\
8.Sosyal yeterlilik &, $434^{* *}$ &, $409^{* *}$ &, $477^{* *}$ &, $481^{* *}$ &, $163^{* *}$ &, $455^{* *}$ &, $521^{* *}$ & & & \\
9.Aile uyumu &, $303^{* *}$ &, $419^{* *}$ &, $160^{* *}$ &, $495^{* *}$ &, 056 &, $274^{* *}$ &, $486^{* *}$ &, $453^{* *}$ & & \\
10.Sosyal kaynaklar &, $414^{* *}$ &, $411^{* *}$ &, $331^{* *}$ &, $495^{* *}$ &, $099^{*}$ &, $386^{* *}$ &, $532^{* *}$ &, $582^{* *}$ &, $651^{* *}$ & \\
11.Yapısal stil &, $431^{* *}$ &, $458^{* *}$ &, $250^{* *}$ &, $417^{* *}$ &, 073 &, $289^{* *}$ &, $495^{* *}$ &, $506^{* *}$ &, $440^{* *}$ &, $502^{* *}$ & \\
12.Dayaniklılı &, $511^{* *}$ &, $568^{* *}$ &, $411^{* *}$ &, $593^{* *}$ &, $180^{* *}$ &, $477^{* *}$ &, $752^{* *}$ &, $785^{* *}$ &, $764^{* *}$ &, $839^{* *}$ &, $708^{* *}$ \\
\hline
\end{tabular}

${ }^{*} \mathrm{p}<0,05$ ve ${ }^{* *} \mathrm{p}<0,01$

Yapılan analize göre kişilik özelliklerinden duygusal denge; gelişime açılık ve öz disiplin ile ilişkili değildir, dışa dönüklük ve uyumluluk ile yüksek düzeyde ilişkilidir. Diğer kişilik özelliklerinin de kendi aralarında yüksek dü- 
zeyde anlamlı ilişkilere sahip olduğu görülmektedir. Ayrıca kişilik özelliklerinin tamamının psikolojik dayanıklılık ile yüksek düzeyde ilişkili olduğu tespit edilmiştir.

Psikolojik dayanıklılığın tüm alt boyutları birbiriyle yüksek düzeyde ilişkilidir. Değişkenlerin alt boyutları incelendiğinde ise kişilik özelliklerinden uyumluluk ile psikolojik dayanıklılık alt boyutlarından kendilik algısı arasinda, yine kişilik özelliklerinden duygusal denge ile psikolojik dayanıklılık alt boyutlarından aile uyumu ve yapısal stil arasında da herhangi bir ilişki tespit edilememiştir. Ancak kişilik özellikleri ile psikolojik dayanıklılığın diğer tüm alt boyutları arasında pozitif yönlü ve güçlü ilişkiler tespit edilmiştir.

Kişilik özelliklerinin cinsiyet değişkeni açısından bir farklılık gösterip göstermediğini tespit etmek için yapılan $\mathrm{T}$ testi sonuçları Tablo 2'de verilmiştir. Analiz sonucunda kişilik özelliklerinden uyumluluk ve duygusal dengenin cinsiyet değişkenine göre farkllık gösterdiği tespit edilmiştir. Buna göre kadınlar uyumluluk özelliği açısından, erkekler ise duygusal denge özelliği açısindan karşı cinsten yüksek ortalamaya sahiptirler.

Tablo 2. Cinsiyet Değişkeni Açısından Kişilik Özellikleri T Testi Sonuçları

\begin{tabular}{lllllll}
\hline Değişkenler & Cinsiyet & N & Ort. & SS & T Değeri & Anlamlılık \\
\hline Uyumluluk & Erkek & 107 & 3,6281 &, 68574 & $-2,713$ & \multirow{2}{*}{007} \\
& Kadın & 315 & 3,8290 &, 58585 & & \\
\hline \multirow{2}{*}{ Duygusal denge } & Erkek & 107 & 3,1814 &, 51771 & 4,598 & \multirow{2}{*}{000} \\
& Kadın & 315 & 2,8943 &, 66314 & & \\
\hline
\end{tabular}

Psikolojik dayanıklılığın cinsiyet değişkeni açısından bir farklılık gösterip göstermediğini tespit edebilmek için T testi yapılmıştır. Sonuçlar Tablo 3' de verilmiştir. Bulgulara göre psikolojik dayanıklılık cinsiyete göre farklılık göstermektedir. Psikolojik dayanıklılık ortalamaları incelendiğinde ise kadınların erkeklere görece daha yüksek ortalamaya sahip oldukları tespit edilmiştir.

Tablo 3. Cinsiyet Değişkeni Açısından Psikolojik Dayanıklılık T Testi Sonuçlan

\begin{tabular}{lcccccc}
\hline Değişkenler & Cinsiyet & N & Ort. & SS & T Değeri & Anlamlılık \\
\hline $\begin{array}{l}\text { Psikolojik } \\
\text { dayanıklılık }\end{array}$ & Erkek & 107 & 3,5130 &, 54713 & $-2,165$ &, 031 \\
\hline & Kadın & 315 & 3,6441 &, 53885 & & \\
\hline
\end{tabular}

Kişilik özelliklerinin alttan dersin olup olmamasına göre bir farklılık gösterip göstermediğini tespit etmek amacıyla yapılan T testi sonuçları Tablo 4 'te verilmiştir. Sonuçlara göre sadece kişilik özelliklerinden uyumluluk katılım- 
cıların alttan dersinin olup olmaması açısından bir farklılık göstermiştir. Alttan dersi olmayanların uyumluluk ortalamaları alttan dersi olanlara göre yüksektir.

Tablo 4. Alttan Ders Değişkeni Açısından Kişilik Özellikleri T Testi Sonuçlan

\begin{tabular}{lllllll}
\hline Değişkenler & Alttan Ders & $\mathbf{N}$ & Ort. & SS & T Değeri & Anlamlılık \\
\hline Uyumluluk & Var & 274 & 3,7303 &, 61339 &, 960 &, 008 \\
\hline & Yok & 140 & 3,9008 &, 61319 & & \\
\hline
\end{tabular}

Kişilik özelliklerinin doğup büyünen yer ile eğitim alınan yerin aynı olup olmamasına göre bir farklılık gösterip göstermediğini tespit etmek maksadıyla yapılan T testi sonuçları Tablo 5'de verilmiştir. Buna göre kişilik özelliklerinden sadece öz disiplin bu açıdan bir farklılık göstermektedir. Doğup büyüdüğü yer Tokat olan katılımcıların öz disiplin ortalaması Tokat dışında doğup büyüyenlere göre yüksektir.

Tablo 5. Doğup Büyünen Yer Açısından Kişilik Özellikleri T Testi Sonuçlarn

\begin{tabular}{lllllll}
\hline Değişkenler & Doğup Büyünen Yer & N & Ort. & SS & T Değeri & Anlamlılık \\
\hline Öz disiplin & Tokat & 319 & 3,6785 &, 67431 & 2,094 &, 037 \\
\hline & Tokat diş1 & 81 & 3,5050 &, 63116 & & \\
\hline
\end{tabular}

Kişilik özelliklerinin harcama açısından farklılık gösterip göstermediğini tespit etmek amaciyla yapılan tek yönlü varyans analizi (ANOVA) sonuçları Tablo 6'da verilmiştir. Analiz sonuçlarına göre kişilik özelliklerinden duygusal denge harcama düzeyi açısından farklılık göstermektedir.

Tablo 6. Harcama Değişkeni Açısından Kişilik Özellikleri Varyans Analizi Sonuçlan

\begin{tabular}{lllllll}
\hline Değişkenler & Harcama Düzeyi & N & Ort. & SS & F Değeri & Anlamlılık \\
\hline \multirow{3}{*}{ Duygusal denge } & $0-499$ TL & 211 & 2,9984 &, 66453 & \multirow{2}{*}{3,939} & \multirow{2}{*}{020} \\
\cline { 2 - 6 } & $500-999 \mathrm{TL}$ & 117 & 2,8884 &, 56226 & & \\
\cline { 2 - 5 } & $1000-5000 \mathrm{TL}$ & 15 & 3,3642 &, 90567 & & \\
\hline
\end{tabular}

Farklılığın hangi gruplar arasında olduğunu tespit etmek için yapılan scheffe testi sonuçları Tablo 7 'de verilmiştir. Sonuçlar değerlendirildiğinde duygusal denge açısından 1.000-5.000 TL harcayanlar ile 500-999 TL harcayanlar arasında anlamlı bir farklılık olduğu görülmektedir. Harcama düzeyi 1.000-5.000 TL olanların duygusal denge ortalamaları 500-999 TL olanların ortalamalarından daha yüksektir. 
Tablo 7. Harcama Düzeyi Açısından Kişilik Özellikleri Scheffe Testi Sonuçları

\begin{tabular}{lllll}
\hline Harcama Düzeyi (I) & Harcama Düzeyi(J) & Ort. Far.(I-J) & Standart Hata & Anlamlılık \\
\hline \multirow{2}{*}{$\mathbf{1 0 0 0 - 5 0 0 0 ~ T L}$} & $0-499 \mathrm{TL}$ &, 36575 &, 17202 &, 106 \\
\cline { 2 - 5 } & $500-999 \mathrm{TL}$ &, 47581 &, 17654 &, 027 \\
\hline
\end{tabular}

Öte yandan yapılan analiz sonuçlarına göre kişilik özellikleri ve psikolojik dayanıklılığın yaş ve alttan ders sayısına göre, ayrıca psikolojik dayanıklılığın alttan dersin olup olmamasına, doğup büyünen yere ve gelir düzeyine göre de anlamlı bir farklılık göstermediği tespit edilmiştir.

Hipotez 1'i test etmek amacıyla, kişilik alt boyutlarının psikolojik dayanıklılık üzerindeki etkisini ortaya çıkarmak için standart çoklu doğrusal regresyon analizi yapılmıştır. Analiz sonuçları Tablo 8'de verilmiştir. Yapılan analize göre regresyon sonuçları anlamlıdır. Ayrıca çoklu regresyon analizinde bağımsız değişkenler arasında güçlü bir korelasyon ilişkisinin varlığ 1 çoklu eş doğrusallık problemini doğurmakta, tolerans değeri kritik değerden (1-R²) büyükse bu problem ortadan kalkmaktadır (Gürbüz ve Şahin, 2016, s. $275,279)$. Analizde elde edilen kritik değer $(1-0,487=0,513)$ tolerans değerlerinin tümünden büyüktür. Bu nedenle analizde çoklu eş doğrusallık probleminin olmadığı sonucuna varılmaktadır.

Düzeltilmiş $\mathrm{R}^{2}$ değeri $0,48^{\prime}$ dir. Bu sonuç psikolojik dayanıklılıktaki \%48 varyansın kişilik özellikleri tarafından açıklandığını göstermektedir. Ancak tablodaki beta katsayılarına bakıldığında kişilik özelliklerinden gelişime açılık, öz disiplin, dışa dönüklük ve uyumluluğun psikolojik dayanıklılığı etkilediği görülmektedir. Duygusal denge ise psikolojik dayanıklılığ1 etkilememektedir. Öz disiplin ve uyumluluğun psikolojik dayanıklılığı diğer kişilik özelliklerinden daha fazla etkileyen özellikler olduğu anlaşılmaktadır. Bu bulgular ışığında kişilik özelliklerinin psikolojik dayanıklıı̆̆ etkilediğini ileri süren $\mathrm{H}_{1}$ hipotezi kısmen desteklenmiştir.

Tablo 8. Kişilik Özellikleri ve Psikolojik Dayanıkhlı̆̆a Ait Çoklu Regresyon Sonuçlarn

\begin{tabular}{|c|c|c|c|c|c|c|c|c|}
\hline Değişk. & Bağımlı Değişk. & $\mathbf{R}$ & $\mathbf{R}^{2}$ & Dztlmş $R^{2}$ & F & Anlaml. & $\beta$ & $t$ \\
\hline Sabit & & & & & & & & 4,333 \\
\hline Gelişime & & & & & & &, $141^{* *}$ & 3,071 \\
\hline $\begin{array}{l}\text { açıklık } \\
\text { Öz disiplin }\end{array}$ & $\begin{array}{l}\text { Psikolojik } \\
\text { dayanıklılık }\end{array}$ & 698 & ,487 & ,481 & 79,096 & ,000 & $282^{* * *}$ & 6,313 \\
\hline Dışa dönüklülk & & & & & & & $175^{* * *}$ & 4,300 \\
\hline Uyumluluk & & & & & & & $286^{* * *}$ & 6,029 \\
\hline Duygusal denge & & & & & & &, 068 & 1,892 \\
\hline
\end{tabular}

${ }^{*} \mathrm{p}<0,05 ;{ }^{* *} \mathrm{p}<0,01 ;{ }^{* * *} \mathrm{p}<0,001$ 
Kişilik özelliklerinin dayanıklılık alt boyutları üzerindeki etkisini tespit edebilmek için çoklu doğrusal regresyon analizi yapılmıştır. İlk olarak kişilik özelliklerinin dayanıklılığın kendilik algısı alt boyutu üzerindeki etkisi araştırılmıştır. Tablo 9'de verilen analiz sonuçlarına göre kendilik algısındaki varyansın \%62'si kişilik özellikleri tarafından açıklanmaktadır. Ancak sonuçlar öz disiplin, dışa dönüklük, uyum ve duygusal dengenin kendilik algısını etkilediğini göstermektedir. Kendilik algısını etkileyen en önemli kişilik özelliğinin ise dışa dönüklük olduğu anlaşılmaktadır.

Tablo 9. Kişilik Özellikleri ve Kendilik Algısına Ait Çoklu Regresyon Sonuçlan

\begin{tabular}{|c|c|c|c|c|c|c|c|c|}
\hline Değişk. & $\begin{array}{l}\text { Bağımlı } \\
\text { Değişk. }\end{array}$ & $\mathbf{R}$ & $\mathbf{R}^{2}$ & Dztlmş R $^{2}$ & $F$ & Anlml. & $\beta$ & $t$ \\
\hline Sabit & & & & & & & & 679 \\
\hline Gelişime açıklık & & & & & & & ,028 & ,715 \\
\hline Öz disiplin & Kendilik & 796 & 634 & 629 & 144,397 & 000 & $269^{* * *}$ & 7,121 \\
\hline Dışa dönüklük & algisı & & & & & &, $592^{* * *}$ & 17,200 \\
\hline Uyumluluk & & & & & & & ,101* & 2,528 \\
\hline Duygusal denge & & & & & & &, $071^{*}$ & 2,327 \\
\hline
\end{tabular}

${ }^{*} \mathrm{p}<0,05 ;{ }^{* *} \mathrm{p}<0,01 ;{ }^{* * *} \mathrm{p}<0,001$

İkinci olarak kişilik özelliklerinin gelecek algısı üzerindeki etkisi araştırılmış, analiz sonuçları Tablo 10' da verilmiştir. Buna göre gelecek algısındaki varyansın \%30'u kişilik özellikleri tarafından açıklanmaktadır. Sonuçlar incelendiğinde gelişime açıklık, öz disiplin ve dışa dönüklüğün gelecek algısını etkilediği görülmektedir. Gelecek algısını etkileyen en önemli kişilik özelliği ise öz disiplindir.

Tablo 10. Kişilik Özellikleri ve Gelecek Algısına Ait Çoklu Regresyon Sonuçlan

\begin{tabular}{|c|c|c|c|c|c|c|c|c|}
\hline Değişk. & $\begin{array}{l}\text { Bağımlı } \\
\text { Değişk. }\end{array}$ & $\mathbf{R}$ & $\mathbf{R}^{2}$ & Dztlmş R $^{2}$ & $F$ & Anlaml. & $\beta$ & $t$ \\
\hline Sabit & & & & & & & & 1,373 \\
\hline Gelişime açıklık & & & & & & &, $123^{*}$ & 2,309 \\
\hline Öz disiplin & Gelecek &, 560 & ,314 & ,306 & 38,150 & ,000 &, $313^{* * *}$ & 6,055 \\
\hline Dışa dönüklük & algis1 & & & & & &, $179^{* * *}$ & 3,802 \\
\hline Uyumluluk & & & & & & & ,095 & 1,725 \\
\hline Duygusal denge & & & & & & & ,072 & 1,729 \\
\hline
\end{tabular}

${ }^{*} \mathrm{p}<0,05 ;{ }^{* *} \mathrm{p}<0,01 ;{ }^{* * *} \mathrm{p}<0,001$

Üçüncü olarak kişilik özelliklerinin sosyal yeterlilik üzerindeki etkisi araştırılmıştır. Araştırma sonuçları Tablo 11'da verilmiştir. Analiz sonuçları sosyal yeterlilikteki \%36 oranındaki değişimin kişilik özelikleri tarafından açılandığını göstermektedir. Ancak sonuçlar öz disiplin, dışa dönüklük ve 
uyumluluğun sosyal yeterliliği etkilediğini ortaya koymaktadır. Sonuçlardan sosyal yeterliliği etkileyen en önemli kişilik özelliğinin ise dışa dönüklük olduğu anlaşılmaktadır.

Tablo 11. Kişilik Özellikleri ve Sosyal Yeterliliğe Ait Çoklu Regresyon Sonuçlan

\begin{tabular}{|c|c|c|c|c|c|c|c|c|}
\hline Değişk. & $\begin{array}{l}\text { Bağımlı } \\
\text { Değişk. }\end{array}$ & $\mathbf{R}$ & $\mathbf{R}^{2}$ & Dztlmş R ${ }^{2}$ & F & Anlaml. & $\beta$ & $t$ \\
\hline Sabit & & & & & & & & 2,313 \\
\hline Gelişime açıklık & & & & & & &, 075 & 1,474 \\
\hline Öz disiplin & Sosyal & 611 &, 374 & ,366 & 49,770 & 000 &, $135^{* *}$ & 2,725 \\
\hline Dışa dönüklük & yeterlilik & & & & & &, $323^{* * *}$ & 7,173 \\
\hline Uyumluluk & & & & & & & $259^{* * *}$ & 4,931 \\
\hline Duygusal denge & & & & & & & ,046 & 1,170 \\
\hline
\end{tabular}

${ }^{*} \mathrm{p}<0,05 ;{ }^{* *} \mathrm{p}<0,01 ;{ }^{* * *} \mathrm{p}<0,001$

Dördüncü olarak kişilik özelliklerinin aile uyumu üzerindeki etkisi araşttrılmış, sonuçlar Tablo 12 'de verilmiştir. Aile uyumundaki varyansın \%26's1 kişilik özellikleri tarafından açılanmaktadır. Ancak sonuçlar kişilik özelliklerinden öz disiplin ve uyumluluğun aile uyumunu etkilediğini göstermektedir. Aile uyumunu etkileyen en önemli kişilik özelliği ise uyumluluktur.

Tablo 12. Kişilik Özellikleri ve Aile Uyumuna Ait Çoklu Regresyon Sonuçlan

\begin{tabular}{|c|c|c|c|c|c|c|c|c|}
\hline Değişk. & $\begin{array}{l}\text { Bağımlı } \\
\text { Değişk. }\end{array}$ & $\mathbf{R}$ & $\mathbf{R}^{2}$ & $\begin{array}{l}\text { Dztlmş } \\
\mathbf{R}^{2}\end{array}$ & F & Anlaml. & $\beta$ & $t$ \\
\hline Sabit & & & & & & & & 4,833 \\
\hline Gelişime açıklık & & & & & & & 023 & 425 \\
\hline Öz disiplin & Aile & ,518 & ,269 & ,260 & 30,632 & ,000 & $185^{* *}$ & 3,471 \\
\hline Dışa dönüklük & uyumu & & & & & & -,004 & -091 \\
\hline Uyumluluk & & & & & & &, $374^{* * *}$ & 6,598 \\
\hline Duygusal denge & & & & & & &,- 013 & -314 \\
\hline
\end{tabular}

${ }^{*} \mathrm{p}<0,05 ;{ }^{* *} \mathrm{p}<0,01 ;{ }^{* * *} \mathrm{p}<0,001$

Beşinci olarak kişilik özelliklerinin sosyal kaynaklar üzerindeki etkisi incelenmiş, analiz sonuçları Tablo 13'de verilmiştir. Sosyal kaynaklardaki varyansın \%29'u kişilik özellikleri tarafından açıklanmaktadır. Duygusal denge hariç tüm kişilik özelliklerinin sosyal kaynakları etkilediği görülmektedir. Sosyal kaynakları etkileyen en önemli kişilik özelliğinin ise uyumluluk olduğu anlaşılmaktadır. 
Tablo 13. Kişilik Özellikleri ve Sosyal Kaynaklara Ait Çoklu Regresyon Sonuçlarn

\begin{tabular}{lllllllll}
\hline Değişk. & $\begin{array}{l}\text { Bağı̆lı } \\
\text { Değişk. }\end{array}$ & $\mathbf{R}$ & $\mathbf{R}^{2}$ & $\begin{array}{l}\text { Dztlmş } \\
\mathbf{R}^{2}\end{array}$ & $\mathbf{F}$ & Anlaml. & $\beta$ & $\mathbf{t}$ \\
\hline Sabit & & & & & & & & 4,611 \\
Geliş̧ime açıklık & & & & & & &, $117^{*}$ & 2,182 \\
Öz disiplin & Sosyal & \multirow{2}{*}{, 553} & \multirow{2}{*}{, 306} &, 298 & 36,772 &, 000 &, $137^{* *}$ & 2,624 \\
Dişa dönüklük & kaynaklar & & & & & &, $150^{* *}$ & 3,169 \\
Uyumluluk & & & & & & &, $306^{* * *}$ & 5,531 \\
Duygusal denge & & & & & &, 005 &, 127 \\
\hline
\end{tabular}

${ }^{*} \mathrm{p}<0,05 ;{ }^{* *} \mathrm{p}<0,01 ;{ }^{* * *} \mathrm{p}<0,001$

Son olarak kişilik özelliklerinin yapısal stilüzerindeki etkisi araştırılmıştır. Sonuçlar Tablo 14'te verilmiştir. Yapısal stildeki varyansın \%27'si kişilik özellikleri tarafından açıklanmaktadır. Ancak sonuçlar yapısal stili gelişime açıklık, öz disiplin ve uyumluluğun etkilediğini göstermektedir. Yapısal stili etkileyen en önemli kişilik özelliğinin ise öz disiplin olduğu görülmektedir.

Tablo 14. Kişilik Özellikleri ve Yapısal Stile Ait Çoklu Regresyon Sonuçları

\begin{tabular}{|c|c|c|c|c|c|c|c|c|}
\hline Değişk. & $\begin{array}{l}\text { Bağımlı } \\
\text { Değişk. }\end{array}$ & $\mathbf{R}$ & $\mathbf{R}^{2}$ & $\begin{array}{l}\text { Dztlmş } \\
\mathbf{R}^{2}\end{array}$ & F & Anlaml. & $\beta$ & $t$ \\
\hline Sabit & & & & & & & & 1,978 \\
\hline Gelişime açılılık & & & & & & & $226^{* * *}$ & 4,157 \\
\hline Öz disiplin & Yapisal &, 532 & 283 & ,274 & 32,841 & 000 &, $276^{* * *}$ & 5,219 \\
\hline Dışa dönüklük & stil & & & & & & ,036 &, 756 \\
\hline Uyumluluk & & & & & & & , $118^{*}$ & 2,105 \\
\hline Duygusal denge & & & & & & & ,004 & ,088 \\
\hline
\end{tabular}

${ }^{*} \mathrm{p}<0,05 ;{ }^{* *} \mathrm{p}<0,01 ;{ }^{* * *} \mathrm{p}<0,001$

Kişilik özelliklerinin dayanıklılık alt boyutları üzerindeki etkisini tespit edebilmek için yapılan çoklu doğrusal regresyon analizi sonuçları değerlendirildiğinde $\mathrm{H} 2$ hipotezi kısmen desteklenmiştir. Kişilik özellikleri dayanıklılığın alt boyutlarını etkilemektedir.

\section{Tartışma ve Sonuç}

Dayanıklılık çalışmaları kişi odaklı ve değişken odaklı (Masten, 2001: 229) olmak üzere iki tür yaklaşıma dayanmaktadır. Bu çalışmada kişi odaklı bakış açısı esas alınarak kişiliğin psikolojik dayanıklılık üzerindeki etkisini ortaya çıkarmak amaçlanmış ve hangi kişilik özelliklerine sahip bireylerin psikolojik açıdan daha dayanıklı olduğu tespit edilmeye çalışılmışır. Ayrıca kişilik özelliklerinin psikolojik dayanıklılığın alt boyutları üzerindeki etkisi araştırılmiştrr. 
Araştırma sonuçları kişilik özelliklerinin psikolojik dayanıklılığı etkilediğini ortaya koymaktadır. Gelişime açık, öz disiplin sahibi, dışa dönük ve uyumlu bireyler psikolojik açıdan daha dayanıklıdır. Elde edilen bu sonuç daha önce de araştırmacılar tarafından ortaya konulmuş olan dayanıklılığın kişinin sahip olduğu özellikler dolayısıyla geliştiği fikrini (Davey vd., 2003; Fayombo, 2010; Liu vd., 2012; Farradinna vd., 2019) kısmen desteklemektedir. Çünkü bu çalışmanın sonuçları kişiliğin duygusal denge hariç dört bileşenin dayanıklılığı etkilediğini, duygusal dengenin ise dayanıklılığı etkilemediğini ortaya koymaktadır.

Analiz sonuçları kişilik özelliklerinin tamamının dayanıklılık ile yüksek düzeyde ilişkili olduğunu göstermektedir. Bu sonuç daha önce yapılmış çalışma sonuçları ile uyum göstermektedir (Friborg, Barlaug, Martinussen, Rosenvinge, ve Hjemdal, 2005; Nakaya, Oshio, ve Kaneko, 2006; Çetin vd., 2015; Polatc1, Irk, Gültekin, ve Sobacı, 2017). Hatta toplam örneklem sayısı 15.609 olan 30 çalışma ile yapılmış bir meta analiz dayanıklılığın bütün kişilik özellikleri ile ilişkili olduğunu ortaya koymaktadır (Oshio, Taku, Hirano, ve Saeed, 2018, s. 54). Bu çalışmada da korelasyon katsayıları kişilik özelliklerinden duygusal dengenin dayanıklılıkla ilişkisini ortaya koymaktadır. Ancak regresyon analizi sonuçları duygusal dengenin dayanıklılığı etkilemediğini göstermektedir. Araştırmanın bu sonucu daha önce duygusal dengesizliğin dayanıklılığı negatif yönde etkilediğini ortaya koyan çalışma sonuçlarıyla (Campbell-Sills, Cohan, ve Stein, 2006; Polatcı vd., 2017; Çavuşoğlu ve Yalçın, 2018) çelişmektedir. Bu durumun örneklem farklılığından kaynaklandığı düşünülmektedir. Meslek yüksekokulu öğrencilerinden oluşan katılımcıların yaşlarının \%70'inin 21'in altında olduğu düşünülürse yaşadıkları duygusal durumlarının henüz onların psikolojik dayanıklılıklarını etkileyecek bir aşamaya gelmediğini söylemek mümkündür. Diğer yandan ilerleyen yaş ve sahip olunan meslekteki deneyimler sonucunda birey duygusal dengesi sayesinde psikolojik olarak daha dayanıklı olabilmekte veya olamamaktadır.

Dayanıklılığı açıklamada tüm kişilik özelliklerinin katkısı eşit değildir. Bu anlamda araştırma sonuçlarına göre öz disiplin ve uyumluluk ön plana çımaktadır. Polatcı ve arkadaşları (2017) da kişiliğin sorumluluk (öz disiplin) boyutunun dayanıklılı̆̆1 pozitif yönde etkileyen en önemli boyut olduğunu tespit etmiştir. Çetin ve arkadaşları (2015) ise dayanıklılığı açıklamada sürece katkı sağlayan en önemli kişilik özelliğinin dişadönüklük olduğunu ortaya koymuşlardır. 
Araştırma sonuçları kişilik özelliklerinin dayanıklılığın alt boyutları üzerinde de etkili olduğunu ortaya koymaktadır. Ancak dayanıklılığın tüm boyutları üzerinde etkili olan tek kişilik özelliği öz disiplindir. Duygusal dengenin ise dayanıklılı̆ıın sadece kendilik algısı boyutu üzerinde etkili olduğu tespit edilmiştir. Kişilik özelliklerinden gelişime açıklık, dayanıklılığın gelecek algısı, sosyal kaynaklar ve yapısal stil boyutlarını etkilemektedir. Yine kişilik özelliklerinden dışa dönüklüğün dayanıklılığın kendilik algısı, gelecek algısı, sosyal yeterlilik ve sosyal kaynaklar boyutlarını etkilediği anlaşılmaktadır. Son olarak da kişilik özelliklerinden uyumluluğun, dayanıklılığın kendilik algisı, sosyal yeterlilik, aile uyumu, sosyal kaynaklar ve yapısal stil boyutlarını etkilediği ortaya çıkarılmıştır. Dayanıklılık boyutlarını etkilemede ön plana çıkan kişilik özelliklerinin öz disiplin, dışa dönüklük ve uyumluluk olduğunu söylemek mümkündür.

Çalışma sonuçlarına göre kişilik özellikleri bakımından kadınların erkeklerden daha uyumlu, erkeklerin de kadınlardan duygusal açıdan daha dengeli olduğu sonucuna varılmıştır. Polatcı ve arkadaşları (Polatcı vd., 2017) da kadınların erkeklere göre daha yüksek düzeyde duygusal dengesizlik yaşadığını tespit etmişlerdir. Ayrıca araştırma sonuçları araştırmaya katılan kadınların erkeklerden daha dayanıklı olduğunu göstermektedir.

Öğrencilerden oluşan örneklem grubuna alttan derslerinin olup olmadığ da sorulmuş, alttan dersi olmayan katılımcıların kişilik özelliği bakımından diğerlerine göre daha uyumlu olduğu tespit edilmiştir. Dollinger ve Orf (1991) ise kişilik özellikleri ve akademik başarı arasındaki ilişkiyi tespit etmek üzere yaptıkları çalışmada öz disiplin ve açıklığın ders notu ve sınav performansını açıkladığını ortaya koymuştur. Doğup büyüdüğü yer ile eğitim aldığı yer aynı olan katılımcıların öz disiplinlerinin daha yüksek olduğu, daha fazla harcama yapan katılımcıların duygusal açıdan daha dengeli oldukları da bu çalışmada ortaya çıkarılan sonuçlar arasındadır.

Bu araştırmada kişilik özelliklerinin psikolojik dayanıklılık üzerindeki etkisi ortaya çıkarılmaya çalışılmış, örneklem olarak da örgütlerin işgören aday havuzunda yer alan meslek yüksekokulu öğrencileri seçilmiştir. Kişilik testleri işgören tedariğinin henüz ilk aşamasında işe uygun personeli seçmek amacıyla yapılabilen testlerdir. Ancak örgütsel davranış disiplininde kişilik sadece bir işe uygun personeli, personele uygun işi seçmek açısından önem arz eden bir husus olarak görülmemelidir. Çünkü kişilik iş tatmini, tükenmiş- 
lik, örgütsel bağlllık gibi değişkenler üzerinde etkili olan psikolojik dayanıklılı̆̆ da büyük ölçüde etkilemektedir. Araştırma sonuçları gelişime açıklık, öz disiplin, dışa dönüklük ve uyumluluk kişilik özelliklerine sahip bireylerin psikolojik açıdan daha dayanıklı olduğunu ortaya koymuşur. Bu yönüyle de hem kişiliğin hem de dayanıklılığın örgütler açısından insan kaynakları süreçlerinde dikkate alınması gereken önemli özellikler olduğu söylenebilir.

Araştırma tek bir ilde ve belirli bir örneklem grubunda yapılmıştır. Araştırmanın farklı örneklemlerde tekrarlanması sonuçların genellenebilmesi açısından faydalı olacaktır. Gelecekte yapılacak çalışmalarda modele farklı değişkenlerin ilave edilmesi de psikolojik dayanıklılığı anlamak açısından yarar sağlayacaktır. 


\title{
EXTENDED ABSTRACT
}

\section{The Effect Of Personality Traits On Psychological Resilience Abstract}

\author{
* \\ Sema Polatc1 - Zeynep Dilara Tinaz \\ Tokat Gaziosmanpaşa University
}

An employees encounter many difficulties almost every day while fulfill his duties in the workplace. To be psychologically resilient is a positive feature that enables the individual to overcome these difficulties in all areas of his life including his job. It has also been experimentally demonstrated that overcoming the difficulties encountered in business life has many positive results for both employee and the organization. Therefore, revealing the factors that affect the psychological resilience of employees is one of the important issues in terms of organizational behavior discipline. The purpose of this study is to reveal effect of personality on psychological resilience and to determine which individuals personality traits are more resilience in terms of psychologically. İn this study also investigated the effect of personality traits on subdimensions of psychological resilience.

The sample of the research consist of 423 vocational school students. The research data were obtained by Five Factor Personality Inventory and the Adult Psychological Resilience Scale. Difference, correlation and regression analyses were performed. As a result of the analysis, it was determined that agreeableness and emotional stability differ according to the gender variable. According to this, females have a higher average in terms of agreeableness and males in terms of emotional stability feature compared to the opposite sex. Again according to the findings psychological resilience also varies accordig to gender. It has been revealed that women have higher average of psychological resilience than men.

The sample group of students was also asked whether they had lesson from lower class. It has been detected that who do not have lesson from lower class are more agreeableness than the others in terms of personality traits. The results of the research also reveal that the conscientiousness average of the participants whose place of birth and education is the same as the place is 
higher than the conscientiousness average of the participants whose place of birth and education is not the same. It is among the results that participants who spend more money have more emotional stability.

The research results reveal that personality traits affects psychological resilience. The results showed that openness to experience, conscientiousness, extraversion and agreeableness of students' personality traits positively affected their psychological resilience. However, the results reveal that four components of personality, except emotional balance, affect resilience, whereas emotional balance does not affect resilience. Although correlation results show that all personality traits are highly correlated with resilience, regression results show that emotional balance has no effect on resilience. Also, the contribution of all personality traits in explaining resilience is not equal. In this sense, according to the results of the research, conscientiousness and compliance come to the fore.

Research results reveal that personality traits are effective in the sub-dimensions of resilience. However, the only personality trait that affects all dimensions of resilience is conscientiousness. On the other hand, emotional stability, was found to be effective only on the perception of self dimension. From personality traits, openness to experience affects the dimensions of resilience that are perception of future, social resources and structural style. Again, one of the personality traits, extraversion affects the perception of self, perception of future, social competence and social resources dimensions of resilience. Finally, it was revealed that the personality trait of agreeableness affect perception of self, social competence, family cohesion, social resources and structural style dimensions of resilience. It is possible to say that the personality traits that come to the fore in affecting the resilience dimensions are conscientiousness, extraversion and agreeableness.

In this study, the effect of personality traits on psychological resilience was tried to be revealed and were selected as a sample vocational school students included in the employee candidate pool of the organizations. Personality tests are tests that can be done in the first stage of employee recruitment to select the appropriate personnel for the job. However, in the discipline of organizational behavior, personality should not be just seen as an important issue in choosing the right personnel for a job and the job suitable for the personnel.Because personality affects the psychological resilience which affects variables such as job satisfaction, burnout, organizational commitment, also 
greatly. The results of the research revealed that individuals with openness to experience, conscientiousness, extraversion and agreeableness personality traits are more psychologically resistant. In this respect, it can be said that both personality and resilience are important features that should be considered in human resources processes for organizations.

The research was conducted in a single province and a specific sample group. Repeating the research in different samples will be beneficial in terms of generalizing the results. Adding different variables to the model in future studies will also be useful in understanding psychological resilience.

\section{Kaynakça / References}

Acaray, A., ve Günsel, A. (2017). Beş faktör kişilik özellikleri, izlenim yönetimi taktikleri ve öznel iyi oluş arasındaki ilişkinin incelenmesi: Kamu çalışanları üzerine bir araştırma. Uluslararası İktisadi ve İdari İncelemeler Dergisi, 16, 527-546. https://doi.org/10.18092/ulikidince.323571

Ahmad, K. Z. Bin, Jasimuddin, S. M., ve Kee, W. L. (2018). Organizational climate and job satisfaction: do employees' personalities matter? Management Decision, 56(2), 421-440. https://doi.org/10.1108/MD-10-2016-0713

Altunışık, R., Coşkun, R., Bayraktaroğlu, S., ve Yıldırım, E. (2004). Sosyal bilimlerde araştırma yöntemleri (3. Baskı). Sakarya: Sakarya Kitabevi.

Antoncic, B., Bratkovic Kregar, T., Singh, G., ve Denoble, A. F. (2015). The Big Five Personality-Entrepreneurship Relationship: Evidence from Slovenia. Journal of Small Business Management, 53(3), 819-841. https://doi.org/10.1111/jsbm.12089

Armon, G., Shirom, A., ve Melamed, S. (2012). The big five personality factors as predictors of changes across time in burnout and its facets. Journal of Personality, 80(2), 403-427. https://doi.org/10.1111/j.1467-6494.2011.00731.x

Bahar, H. H., ve Kağan, M. (2018). Öğretmen adaylarında özyeterlik algılarının yordayıcısı olarak beş faktör kişilik özellikleri. Erzincan Üniversitesi Eğitim Fakültesi Dergisi, 20(3), 676-686. https://doi.org/10.17556/erziefd.406102

Bakker, A. B., Van Der Zee, K. I., Lewig, K. A., ve Dollard, M. F. (2006). The relationship between the big five personality factors and burnout: A study among volunteer counselors. Journal of Social Psychology, 146(1), 31-50. https://doi.org/10.3200/SOCP.146.1.31-50

Barric, M. R., ve Mount, M. K. (1991). The big five personalty dimension and job performance: A meta-analysis. Personnel Psychology, 44(1), 1-26. https://doi.org/10.1111/j.1744-6570.1991.tb00688.x 
Basım, H. N., Çetin, F., ve Tabak, A. (2009). Beş faktör kişilik özelliklerinin kişilerarası çatışma çözme yaklaşımlarıyla ilişkisi. Türk Psikoloji Dergisi, 24(63), 2034. http://www.academia.edu/download/38292553/Bes-faktor-kisilik-ozelliklerinin-kisilerarasi-catisma-cozme-yaklasimlariyla-iliskisi.pdf adresinden erişilmiştir.

Baymur, F. B. (2017). Genel psikoloji (26. Bask1). İstanbul: İnkılap Kitabevi.

Bayat, G. (2019). Beş faktör kişilik özellikleri ve konaklama işletmeleri çalışanları kişilik özelliklerinin iş doyumu düzeyleri üzerindeki etkisi. Işletme Araştırmalan Dergisi, 11(3), 1575-1588. https://doi.org/10.20491/isarder.2019.690

Benet-Martínez, V., ve John, O. P. (1998). Los Cinco Grandes across cultures and ethnic groups: Multitrait multimethod analyses of the big five in Spanish and English. Journal of Personality and Social Psychology, 75(3), 729-750. https://doi.org/10.1037/0022-3514.75.3.729

Bitlisli, F., Dinç, M., Çetinceli, E., ve Kaygisiz, Ü. (2013). Beş faktör kişilik özellikleri ile akademik güdülenme ilişkisi: Süleyman Demirel Üniversitesi Isparta Meslek Yüksekokulu öğrencilerine yönelik bir araştırma. Süleyman Demirel Üniversitesi İktisadi ve İdari Bilimler Fakültesi Dergisi, 18(2), 459-480.

Bonanno, G. A. (2004). Loss, trauma, and human resilience: Have we underestimated the human capacity to thrive after extremely aversive events? American Psychologist, 59(1), 20-28. https://doi.org/10.1037/0003-066X.59.1.20

Burger, J. M. (2006). Kişilik (1. Bask1). İstanbul: Kaknüs Yayınları.

Campbell-Sills, L., Cohan, S. L., ve Stein, M. B. (2006). Relationship of resilience to personality, coping, and psychiatric symptoms in young adults. Behaviour Research and Therapy, 44(4), 585-599. https://doi.org/10.1016/j.brat.2005.05.001

Çavuşoğlu, S., ve Yalçın, M. (2018). Banka çalışanlarının kişilik özelliklerinin psikolojik dayanıklılık düzeylerine etkisi. Celal Bayar Üniversitesi Sosyal Bilimler Dergisi, 16(2), 49-76. Retrieved from https://dergipark.org.tr/tr/pub/cbayarsos/issue/38081/439420

Çetin, F., ve Basım, H. N. (2011). Psikolojik dayanıklılığın iş tatmini ve örgütsel bağl1lık tutumlarındaki rolü. İş, Güç Endüstri İiş̧kileri ve Insan Kaynaklan Dergisi, 13(3), 81. https://doi.org/10.4026/1303-2860.2011.184.x

Çetin, F., Yeloğlu, H. O., ve Basım, H. N. (2015). Psikolojik dayanıklılığın açıklanmasinda beş faktör kişilik özelliklerinin rolü: Bir kanonik ilişki analizi. Türk Psikoloji Dergisi, 30(75), 81-92. 
Chitra, T., ve Karunanidhi, S. (2013). Influence of occupational stress, resilience, and job satisfaction on psychological well-being of policewomen. Indian Journal of Health and Wellbeing, 4(4), 724-730. http://search.proquest.com/openview/7f03846033d316d6beac2055cc58bf39/1?pq-origsite=gscholar\&cbl=2032134 adresinden erişilmiştir.

Costa, P. T., McCrae, R. R., ve Dye, D. A. (1991). Facet scales for agreeableness and conscientiousness: A revision of tshe NEO personality inventory. Personality and Individual Differences, 12(9), 887-898. https://doi.org/10.1016/01918869(91)90177-D

Dalton, M., ve Wilson, M. (2000). The relationship of the five-factor model of personality to job performance for a group of Middle Eastern Expatriate managers. Journal of Cross-Cultural Psychology, 31(2), 250-258. https://doi.org/10.1177/0022022100031002007 adresinden erişilmiştir.

Davey, M., Eaker, D. G., ve Walters, L. H. (2003, July 25). Resilience processes in adolescents: Profiles, self-worth, and coping. Journal of Adolescent Research, 18, 347-362. https://doi.org/10.1177/0743558403018004002

Dinç, M., Bitlisli, F., Çetinceli, E., ve Aydın, S. Z. (2013). Öğretim elemanlarının tükenmişliğinde beş faktör kişilik özelliklerinin etkisi: Süleymen Demirel Üniversitesi Meslek Yüksekolulları örneği. Süleyman Demirel Üniversitesi Vizyoner Dergisi, 4(9), 44-69. Retrieved from https://dergipark.org.tr/tr/pub/vizyoner/issue/23008/246062

Doğan, T. (2013). Beş Faktör kişilik özellikleri ve öznei iyi oluş. Doğuş Üniversitesi Dergisi, 14(1), 56-64. http://journal.dogus.edu.tr/index.php/duj/article/view/585

Dollinger, S. J., ve Orf, L. A. (1991). Personality and Performance in "Personality": Conscientiousness and openness. Journal of Research in Personality, 25(3), 276284. https://doi.org/10.1016/0092-6566(91)90020-Q

Erkuş, A. (2011). Çok boyutlu lider-izleyici etkileşiminde kişilik özelliklerinin ve güç kaynaklarının rolü. Atatürk Üniversitesi İktisadi ve İdari Bilimler Dergisi, 25(1), 127-152. Retrieved from https://dergipark.org.tr/en/pub/atauniiibd/is$\underline{\text { sue } / 2697 / 35631}$

Erkuş, A., ve Tabak, A. (2009). Beş faktör kişilik özelliklerinin çalışanların çatışma yönetim tarzlarına ertkisi: Savunma sanayiinde bir araştırma. Atatürk Üniversitesi İktisadi ve İdari Bilimler Dergisi, 23(2), 213-242. Retrieved from https://dergipark.org.tr/en/pub/atauniiibd/issue/2696/35515

Erkutlu, H. (2012). Impact of Psychological Hardiness and Self-Monitoring On Teacher Burnout. Hacettepe Üniversitesi Ĕ̆itim Fakültesi Dergisi, 43(43), 186-197. 
Erol, E. (2010). Örgütsel davranış ve yönetim psikolojisi (12. Baskı). İstanbul: Beta Basım Yayım Dağitım.

Farradinna, S., Nila Fadhlia, T., ve Azmansyah, D. (2019). Psychological resilience predicted by personality traits, locus of control and self-regulation of young entrepreneurs in Pekanbaru. Global Journal of Business and Social Science Review, 7(1), 75-83. www.gatrenterprise.com/GATRJournals/index.html adresinden erişilmiştir.

Fayombo, G. A. (2010). The relationship between personality traits and psychological resilience among the Caribbean Adolescents. International Journal of Psychological Studies, 2(2). https://doi.org/10.5539/ijps.v2n2p105

Friborg, O., Barlaug, D., Martinussen, M., Rosenvinge, J. H., ve Hjemdal, O. (2005). Resilience in relation to personality and intelligence. International Journal of Methods in Psychiatric Research, 14(1), 29-42. https://doi.org/10.1002/mpr.15

Friborg, O., Hjemdal, O., Rosenvinge, J. H., ve Martinussen, M. (2003). A new rating scale for adult resilience: What are the central protective resources behind healthy adjustment? International Journal of Methods in Psychiatric Research, 12(2), 65-76. https://doi.org/10.1002/mpr.143

Furnham, A., Crump, J., ve Whelan, J. (1997). Validating the Neo Personality İnventory Using Assessor's Ratings. Personality and Individual Differences, 22(5), 669-675. https://doi.org/10.1016/S0191-8869(96)00261-9

García-Izquierdo, M., Meseguer de Pedro, M., Ríos-Risquez, M. I., ve Sánchez, M. I. S. (2018). Resilience as a moderator of psychological health in situations of chronic stress (burnout) in a sample of hospital nurses. Journal of Nursing Scholarship, 50(2), 228-236. https://doi.org/10.1111/jnu.12367

Gençtanırım Kurt, D., ve Çetinkaya Yıldız, E. (2017). Kişilik kuramları (2. Baskı). Ankara: Pegem Akademi.

Goldberg, L. (1995). What the hell took so long? Donald W. Fiske and the big-five factor structure. P. E. Shrout veS. T. Fiske(Eds.), PersonalityResearch, Methods, and Theory içinde(s. 29-43). New Jersey: Lawrence Erlbaum Associates.

Gürbüz, S., ve Şahin, F. (2016). Sosyal Bilimlerde Araştırma Yöntemleri. Ankara: Seçkin Yayincilik.

Huang, J. L., Ryan, A. M., Zabel, K. L., ve Palmer, A. (2014). Personality and adaptive performance at work: A meta-analytic investigation. Journal of Applied Psychology, 99(1), 162-179. https://doi.org/10.1037/a0034285 adresinden erişilmiştir. 
Joardar, A., ve Matthews, L. M. (2010). An empirical İnvestigation of Group Acceptance Using the Big Five Personality Domains. Organisation Management Journal, 7(3), 194-207. https://doi.org/10.1057/omj.2010.26

Kaba, İ., ve Keklik, İ. (2016). Öğrencilerin üniversite yaşamına uyumlarında psikolojik dayanıklılk ve psikolojik belirtiler. Hacettepe Üniversitesi Eğitim Bilimleri Enstitüsü Eğitim Araştırmalarn Dergisi, 2(2), 98-113. http://dergipark.ulakbim.gov.tr/huner adresinden erişilmiştir.

Karacabey, M. F., ve Bozkuş, K. (2019). Psikolojik sağlamlı̆ın, tükenmişlik, iş tatmini ve örgütsel bağlllı̆̆a etkisi: Suriyeli Göçmenlerin Türkçe öğretmenleri üzerinde bir uygulama. İs, Güç: The Journal of Industrial Relations and Human Resources, 95-110. https://doi.org/10.4026/isguc.563065

Kardaş, S. (2018). Beş faktör kişilik özelliklerinin iş tatmini üzerindeki etkisi. Yayımlanmamış yüksek lisans tezi. İstanbul Ticaret Üniversitesi, Sosyal Bilimler Enstitüsü, İstanbul. Retrieved from http://acikerisim.ticaret.edu.tr/xmlui/handle/11467/2041

Kashyap, S. P., Kumar, S., ve Krishna, A. (2014). Role of resilience as a moderator between the relationship of occupational stress and psychological health. Indian Journal of Health ve Wellbeing, 5(9), 10-23. https://www.researchgate.net/publication/271139299 adresinden erişilmiştir.

Li, Y., Cao, F., Cao, D., ve Liu, J. (2015). Nursing Students' Post-traumatic Growth, Emotional İntelligence And Psychological Resilience. Journal of Psychiatric and Mental Health Nursing, 22(5), 326-332. https://doi.org/10.1111/jpm.12192

Liu, Y., Wang, Z. H., ve Li, Z. G. (2012). Affective mediators of the influence of neuroticism and resilience on life satisfaction. Personality and Individual Differences, 52(7), 833-838. https://doi.org/10.1016/j.paid.2012.01.017

Masten, A. S. (2001). Ordinary magic resilience processes in development. https://doi.org/10.1037/0003-066X.56.3.227

McCann, S. J. H. (2018). U.S. State resident big five personality and work satisfaction: The importance of neuroticism. Cross-Cultural Research, 52(2), 155-191. https://doi.org/10.1177/1069397117723607

McCrae, R. R., ve Costa, P. T. (2003). Personality in adulthood (Second E. ). New Yok: The Guilford Press.

Merdan, E. (2013). Beş faktör kişilik kuramı ile iş değerleri ilişkisinin incelenmesi: Bankacılık sektöründe bir araştırma. Gümüşhane Üniversitesi Sosyal Bilimler Elektronik Dergisi, 7. http://eds.a.ebscohost.com/eds/pdfviewer/pdfviewer?vid=0\&sid=fddd972c -f80a-423c-a0fa-b0016733ce5c\%40sdc-v-sessmgr03 adresinden erişilmiştir. 
Nakaya, M., Oshio, A., ve Kaneko, H. (2006). Correlations for Adolescent Resilience Scale with big Five Personality Traits. Psychological Reports, 98(3), 927-930. https://doi.org/10.2466/PR0.98.3.927-930

Neal, A., Yeo, G., Koy, A., ve Xiao, T. (2012). Predicting the form and direction of work role performance from the Big 5 model of personality traits. Journal of Organizational Behavior, 33(2), 175-192. https://doi.org/10.1002/job.742 adresinden erişilmiştir.

Olsson, C. A., Bond, L., Burns, J. M., Vella-Brodrick, D. A., ve Sawyer, S. M. (2003). Adolescent resilience: A concept analysis. journal of Adolescence, 26(1), 1-11. https://doi.org/10.1016/S0140-1971(02)00118-5

Ono, M., Sachau, D. A., Deal, W. P., Englert, D. R., ve Taylor, M. D. (2011). Cognitive ability, emotional intelligence, and the big five personality dimensions as predictors of criminal investigator performance. Criminal Justice and Behavior, 38(5), 471-491. https://doi.org/10.1177/0093854811399406 adresinden erişilmiştir.

Oshio, A., Taku, K., Hirano, M., ve Saeed, G. (2018). Resilience and big five personality traits: A meta-analysis. Personality and Individual Differences, 127, 54-60. https://doi.org/10.1016/j.paid.2018.01.048 adresinden erişilmiştir.

Ötken, A. B., ve Cenkci, T. (2013). Beş faktör kişilik modeli ve örgütsel muhalefet arasındaki ilişki üzerine bir araştırma. Öneri Dergisi, 10(39), 41-51. https://doi.org/10.14783/OD.V10I39.1012000306

Polatcı, S., Irk, E., Gültekin, Z., ve Sobacı, F. (2017). Psikolojik Dayanıklılık ve Kişilik Özellikleri Tatmin Düzeyini Etkiler mi? Süleyman Demirel Üniversitesi Sosyal Bilimler Enstitüsü Dergisi, 29, 553-578. https://www.researchgate.net/publication/322163309 adresinden erişilmiştir.

Polatçı, S., Sobacı, F., ve Kaban, İ. (2019). Beş faktör kişilik özellikleri ve kişi iş uyumunun iş tatmini üzerine etkileri taşeron firma elemanları üzerine bir araştırma. Journal of Organizational Behavior Review, 2(1), 12-30. Retrieved from https://www.researchgate.net/publication/325273293

Riolli, L., Savicki, V., ve Cepani, A. (2002). Resilience in the face of catastrophe: Optimism, personality, and coping in the Kosovo Crisis. Journal of Applied Social Psychology, 32(8), 1604-1627. $\quad$ https://doi.org/10.1111/j.15591816.2002.tb02765.x

Rutter, M. (2006). Implications of resilience concepts for scientific understanding. Annnals New York Academy of Sciences, 1094. https://doi.org/10.1196/annals.1376.002 
Santos, A., Mustafa, M., ve Chern, G. T. (2016). The Big Five personality traits and burnout among Malaysian HR professionals. Asia-Pacific Journal of Business Administration, 8(1), 2-20. https://doi.org/10.1108/APJBA-09-2014-0106

Schultz, D. P., ve Schultz, S. E. (2013). Therories of personality (10. Bask1). Amerika: wadsworth Cengage Learning.

Şimşek, E., ve Aktaş, H. (2015). Örgütsel sessizlik ile kişilik ve yaşam doyumu etkileşimi: Kamu sektöründe bir araştırma. Anadolu Üniversitesi Sosyal Bilimler Dergisi, 14(2), 121-136. https://doi.org/10.18037/ausbd.16857

Somer, O. (2001). Çeşitli çalışma alanlarının beş faktör kişilik boyutlarıyla ilişkisi. Ege Eğitim Dergisi, 1(1), 31-40.

Somer, O., Korkmaz, M., ve Tatar, A. (2002). Beş Faktör Kişilik Envanteri'nin Geliştirilmesi I: Ölçek ve Alt Ölçeklerin Oluşturulması (Development of the Five Factor Personality Inventory). Türk Psikoloji Dergisi, 17(49), 21-33. https://www.researchgate.net/publication/284054468 Bes Faktor adresinden erişilmiştir.

Sood, S., ve Puri, D. (2016). Big Five Personality Factors: Its Role in Determining Organizational Commitment. Indian Association of Health, Research, and Welfare, 6(4),425-431. $\quad$ https://search.proquest.com/docview/1865736125/fulltextPDF/9375FA9A6E7A44D4PQ/3?accountid=15959 adresinden erişilmiştir.

Tabak, A., Basım, N., Tatar, İ., ve Çetìn, F. (2010). İzlenim yönetimi taktiklerinde beş faktör kişilik özelliklerinin rolü: Savunma sanayiinde bir araştırma. Ege Akademik Bakış, 10(2), 539-557.

Tatar, A., Saltukoğlu, G., Özdemir, H., Bekiroğlu, B., Çelikbaş, B., ve Çamkerten, S. (2019). Altı faktörlü kişilik modeline (hexaco) dayalı olarak iş performansı ve iş doyumunun yordanması. İş'te Davranış Dergisi, 4(2), 68-77. https://doi.org/10.25203/idd.629879 adresinden erişilmiştir.

Tekin, Ö. A., Turan, S. N., Özmen, M., Turhan, A. A., ve Kökçü, A. (2012). Beş faktör kişilik özellikleri ve örgütsel çatışma yönetimi arasındaki ilişkiler: Ankara'daki beş yıldızlı otel işletmeleri üzerine bir uygulama. Journal of Yaşar University, 27(7), 4611-4641. https://doi.org/10.19168/IYU.84228 adresinden erişilmiştir.

Tozkoparan, G. (2013). Beş faktör kişilik özelliklerinin çatışma yönetim tarzlarına etkisi: yöneticiler üzerine bir araştırma. Ekonomik ve Sosyal Araştırmalar Dergisi, 9(9), 189-231. Retrieved from https://dergipark.org.tr/en/download/articlefile/69318 
Turhan, Ö. (2019). Beş faktör kişilik özelliklerinin iş tatmini üzerindeki etkisinde depresyonun aracllk rolï. Journal of International Scientific Researches, 4(3), 464481. https://doi.org/10.21733/ibad.559860 adresinden erişilmiştir.

Ulu, S., Özdevecioğlu, M., ve Ardiç, K. (2016). Kişilik özelliklerinin hasta iken işe gelme (presenteizm) davranışı üzerindeki etkileri: İmalat sanayiinde bir araştırma. Erciyes Üniversitesi İktisadi ve İdari Bilimler Fakültesi Dergisi, 47, 167181.

Yang, J., Tang, S., ve Zhou, W. (2017). Psychological resilience and job satisfaction: the mediating effect of positive affectivity. In Revista Argentina de Clínica Psicológica, XXVI(2), 194-201

Yazgan İnanç, B., ve Yerlikaya, E. E. (2011). Kişilik kuramları (5. Baskı). Ankara: Pegem Akademi.

Yıldızoğlu, H., ve Burgaz, B. (2014). Okul Yöneticilerinin Beş Faktör Kişilik Özellikleriyle Çatışma Yönetimi Stili Tercihleri Arasındaki Ilişki. Hacettepe Üniversitesi Eğitim Fakültesi Dergisi, 29. https://dergipark.org.tr/en/pub/hunefd/issue/7788/101823 adresinden erişilmiştir.

Yurtsever, H. (2009). Kişilik özelliklerinin stres düzeyine etkisi ve stresle başa çıkma yollarn: Üniversite öğrencileri üzerine bir araştırma. Yayımlanmamış yüksek lisans tezi). Dokuz Eylül Üniversitesi, İzmir.

Zhai, Q., Willis, M., O'Shea, B., Zhai, Y., ve Yang, Y. (2013). Big five personality traits, job satisfaction and subjective wellbeing in China. International Journal of Psychology, 48(6), 1099-1108. https://doi.org/10.1080/00207594.2012.732700

\section{Kaynakça Bilgisi / Citation Information}

Tinaz, Z. D. ve Polatcı, S. (2021). Kişilik özelliklerinin psikolojik dayanıklılık üzerindeki etkisi. OPUS-Uluslararası Toplum Araştırmaları Dergisi, 17(36), 2890-2917. DOI: 10.26466/opus.827411 